Note

\section{Partial Purification and Study of Some Properties of Rice Germ Lipoxygenase}

\author{
Aijiro Yamamoto, * Yoshiharu FujI, \\ Kyoden Yasumoto and Hisateru MitsudA** \\ Department of Food Science and Technology, \\ Faculty of Agriculture, Kyoto University, \\ Sakyo-ku, Kyoto 606
}

Received July 27, 1979

Development of stale flavor in rice grain is one of unfavorable changes occurring during storage, and thus is barring institution of an increasing plan for the national stock holdings. Hexanal is generally accepted as one of the major components responsible for objectional off-flavors developing in many plant foods. In long-term-stored rice kernels, hexanal is also an important flavor contributor, arising presumably from decomposition of hydroperoxides of unsaturated fatty acids ${ }^{1)}$. Lipoxygenase (EC 1.13.11.12) is implicated with heme proteins in the hydroperoxide production in many plant tissues. Yet, presence of lipoxygenase in rice grain has not been established unequivocally, though Shastry et al. attributed the hydroperoxidizing activity present in rice bran to a lipoxygenase reaction. ${ }^{2)}$ The present investigation was undertaken to give more detailed characterization of this activity so that we can understand more precisely the mechanism by which the stale flavor components ariser in stored rice. In this paper, we describe the partial purification and characterization of lipoxygenase from rice germ.

Lipoxygenase activity was determined polarographically and spectrophotometrically as described previously. ${ }^{3)}$ The standard assay conditions were, unless otherwise stated, $0.01 \mathrm{~m} \mathrm{Na}$-linoleate, $0.1 \mathrm{~m}$ phosphate buffer $\left(\mathrm{pH} 7.0\right.$ ) and $240 \mu \mathrm{M} \mathrm{O}_{2}$ (in equilibrium with air at $25^{\circ} \mathrm{C}$ ). The enzyme activity was expressed in katals.

A relatively high lipoxygenase activity was detected in the unfractionated fresh rice bran which was successively removed from brown rice of different japonica varieties in a laboratory test mill (an abrasive type). The unfractionated bran, corresponding to the out-

* Present address: Koshien University, Momijigaoka, Takarazuka 665.

* Present address: Research Institute for Production Development, 15 Morimotocho, Sakyo-ku, Kyoto 606. side layers of brown rice, is composed of the pericarp, the seed coat, most of aleurone layer, broken kernels, and the whole of the germ removed together with these bran components. However, the enzyme activity was found not distributing uniformly among the bran components but localized mostly, if not entirely, in the germ fraction (Table I). This localization, hitherto not fully realized, conduced to the purification of lipoxygenase.

TABle I. LipoXygenase ACtIVITY IN UNFRACTIONATED RICE BRAN

\begin{tabular}{lcc}
\hline & $\begin{array}{c}\text { Total } \\
\text { activity } \\
(\mu \mathrm{kat} / \mathrm{kg} \\
\text { material) }\end{array}$ & $\begin{array}{c}\text { Specific } \\
\text { activity } \\
(\mu \mathrm{kat} / \mathrm{kg} \\
\mathrm{protein})\end{array}$ \\
\hline Unfractionated rice bran & 5.80 & 71.5 \\
Bran fraction & 4.22 & 62.5 \\
Germ fraction & 12.0 & 160 \\
\hline
\end{tabular}

Unfractionated rice bran from a japonica variety (Nipponbare, 1976) was passed through 20 and 32 mesh sieves to separate into the bran and germ fractions. The two fractions were extracted with 4 volume of acetate buffer ( $\mathrm{pH} 4.5$ ) and the resultant extracts were assayed for the enzyme activity under the standard assay conditions.

The enzyme purification procedure involved extraction of powdered rice germ with $0.1 \mathrm{M}$ acetate buffer ( $\mathrm{pH} 4.5$ ), and fractionation of the protein with ammonium sulfate precipitation, heat treatment, and column chromatography on a DEAE-Sephadex column. Table II summarizes the results of a typical purification. Disc electrophoresis on $7 \%$ polyacrylamide $\mathrm{gel}^{5)}$ of the peak fraction obtained in the gel filtration on a Sephadex G-100 column gave one major protein band bearing lipoxygenase activity and two trace protein bands both being negative in activity staining reaction of Guss et al. ${ }^{8}$ The result indicates homogeneity of the final preparation with respect to lipoxygenase. The molecular weight of the enzyme estimated by the gel filtration method was 95,000 .

Properties of the isolated rice germ enzyme were typical of lipoxygenase, standing comparison with those of soybean lipoxygenase-a. ${ }^{8,7,8)}$ Initial velocity of the reaction was proportional to the enzyme concentration in both polarographic and spectrophotometric assays. This linear relationship is characteristics of the lipoxygenase-catalyzed reaction and distinct from those nonlinear relationships usually observed for the reactions catalyzed nonspecificially by many heme proteins. The rice germ enzyme reaction was highly specific for linoleic and linolenic acids, with a $\mathrm{Km}$ value of $0.10 \mathrm{~mm}$ for Na-linoleate. Trilinolein and methyl linoleate were the less effective substrate and oleic acid was inactive. The reaction was optimal 
Table II. Summary of the Purification Procedure for Rice Germ Lrpoxygenase

\begin{tabular}{|c|c|c|c|c|c|}
\hline Fraction & $\begin{array}{l}\text { Total } \\
\text { protein } \\
\text { (g) }\end{array}$ & $\begin{array}{c}\text { Total } \\
\text { activity } \\
(\mu \text { kat })\end{array}$ & $\begin{array}{c}\text { Recovery of } \\
\text { activity } \\
(\%)\end{array}$ & $\begin{array}{c}\text { Specific } \\
\text { activity } \\
\text { (mkat } / \mathrm{kg} \text { ) }\end{array}$ & $\begin{array}{l}\text { Purifi- } \\
\text { cation } \\
\text { (fold) }\end{array}$ \\
\hline Crude extract & 255 & 73.2 & 100 & 0.287 & 1.00 \\
\hline $\begin{array}{l}\left(\mathrm{NH}_{4}\right)_{2} \mathrm{SO}_{4}, 30 \sim 70 \% \\
\text { saturation }\end{array}$ & 133 & 100 & 137 & 0.753 & 2.62 \\
\hline $\begin{array}{l}\text { Heat treatment, } \\
\qquad 63^{\circ} \mathrm{C}, 5 \mathrm{~min}\end{array}$ & 43.8 & 63.1 & 86.1 & 1.44 & 5.02 \\
\hline $\begin{array}{l}\left(\mathrm{NH}_{4}\right)_{2} \mathrm{SO}_{4}, 0 \sim 70 \% \\
\text { saturation }\end{array}$ & 11.2 & 46.6 & 63.7 & 4.16 & 14.5 \\
\hline \multicolumn{6}{|l|}{ DEAE-Sephadex: } \\
\hline Pooled fractions & 0.365 & 27.2 & 37.1 & 74.5 & 260 \\
\hline Peak fraction & 0.0176 & 2.45 & - & 139 & 484 \\
\hline
\end{tabular}

Rice germ from a japonica brown rice (Gohyakumangoku, 1976) was ground in a Centri-mill and $5 \mathrm{~kg}$ of the resultant powder was homogenized with 251 of $0.1 \mathrm{M}$ acetate buffer $(\mathrm{pH} 4.5)$. Purification was compared in relative to the crude extract.

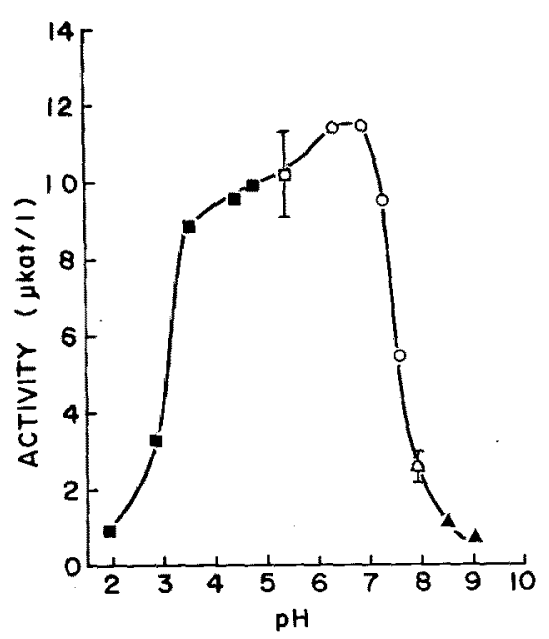

FIG. 1. pH-Activity Profile for Isolated Rice Germ Lipoxygenase.

The enzyme activity was determined under the standard assay conditions except that $\mathrm{pH}$ of the reaction medium was varied using the following buffers: acetate (-- for $\mathrm{pH} 2.0$ to 6.0 , potassium phosphate $(\mathrm{O}-\mathrm{O})$ for $\mathrm{pH} 6.0$ to 8.0 , and borate $(\mathbf{\Delta - \Lambda})$ for $\mathrm{pH} 8.0$ to 9.0 .

at around $\mathrm{pH} 6.5$ to 7.0 as shown in Fig. 1. The enzyme proved stable at temperature up to $60^{\circ} \mathrm{C}$ and could be stored over a month in a refrigerator without any significant loss of activity.

The rice germ enzyme lost more than $60 \%$ of the original activity on incubation with $0.1 \mathrm{mM} \mathrm{H}_{2} \mathrm{O}_{2}$, which was discovered previously as a specific inactivator of lipoxygenase. ${ }^{\beta)}$ This finding provides an unequivocal evidence supporting our identification that the isolated enzyme is a member of true lipoxygenase. Among those divalent cations which affected little the enzyme activity at a concentration up to $10 \mathrm{mM}$ were included $\mathrm{Mg}^{2+}, \mathrm{Sr}^{2+}, \mathrm{Ba}^{2+}, \mathrm{Mn}^{2+}, \mathrm{Ni}^{2+}$ $\mathrm{Cu}^{2+}$, and $\mathrm{Cd}^{2+}$. Calcium ion also neither activated nor inhibited the enzyme in the crude extracts and in a highly purified preparation both at $\mathrm{pH} 7$ and 9 . This immunity to added $\mathrm{Ca}^{2+}$ is not parallel with the susceptibility of soybean enzymes. ${ }^{7}$ The rice germ enzyme activity was not modified to any detectable extent by incubation at $25^{\circ} \mathrm{C}$ for $50 \mathrm{hr}$ with $10 \mathrm{~mm}$ $\mathrm{NaN}_{3}, \mathrm{NaCN}$, and $\mathrm{NaF}$ respectively.

The rice germ enzyme was inhibited about $40 \%$ by $10 \mathrm{mM}$ EDTA, while not by other chelators such as 8-hydroxyquinoline, tiron, 2,2'-dipyridyl, o-phenanthroline, dithizone and pyrophosphate. The specific action of added EDTA remains to be accounted for precisely.

Some of the experimental results we obtained for the rice germ enzyme are apparently inconsistent with those reported by Shastry et al., ${ }^{2)}$ who showed that partially purified lipoxygenase from unfractionated rice bran of an indica variety is optimal at around pH 8.5, inhibited by $\mathrm{Ca}^{2+}$ and activated by both $\mathrm{Fe}^{2+}$ and EDTA. Although further work is required to explain fully those discrepancies, possible explanation might involve variety and tissue variations of rice lipoxygenase: japonica versus indica varieties and germ versus bran portions.

A preliminary study on the positional specificity of the reaction product indicated that the rice germ enzyme gave predominantly 9-hydroperoxide from linoleic acid in contrast to soybean lipoxygenase-a which yielded exclusively the 13-hydroperoxide. The physiological implication of rice germ enzyme will be discussed elsewhere pursuant to its positional- and stereo-specificity.

The authors are grateful to Okura Shuzo Co., Ltd. for kindly providing rice germ for authors' use. 


\section{REFERENCES}

1) K. Yasumatsu, S. Moritaka and S. Wada, Agric. Biol. Chem., 30, 483 (1964).

2) B.S. Shastry and M.R. Raghavendra Rao, Cereal Chem., 52, 597 (1975).

3) H. Mitsuda, K. Yasumoto, A. Yamamoto and T. Kusano, Agric. Biol. Chern., 31, 115 (1967).

4) IUPAC-IUB Commission on Biochemical Nomenclature. Enzyme Nomenclature Recom- mendations (1972).

5) L. Ornstein and B. J. Davis, Ann. N. Y. Acad. Sci., 121, 321 (1964).

6) P. L. Guss, T. Richardson and M. A. Stahmann, Cereal Chem., 44, 607 (1967).

7) A. Yamamoto, K. Yasumoto and H. Mitsuda, Agric. Biol. Chem., 34, 1169 (1970).

8) H. Mitsuda, K. Yasumoto, and A. Yamamoto, Agric. Biol. Chem., 31, 853 (1967). 